\title{
Response to the Letter by Kosker et al. Entitled 'Choroidal Changes in Patients with Familial Mediterranean Fever'
}

\author{
Fatih C. Gundogan ${ }^{\mathrm{a}}$ Salih Uzun ${ }^{\mathrm{b}}$ Fahrettin Akay ${ }^{c}$ Gökhan Özge ${ }^{\mathrm{a}}$

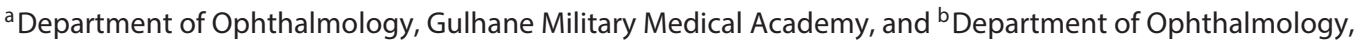 \\ Etimesgut Military Hospital, Ankara, and ' Department of Ophthalmology, Izmir Military Hospital, Izmir, Turkey
}

\section{Dear Editor}

We have read Kosker et al.'s comments [1] on our article entitled 'Choroidal Thickness Changes in the Acute Attack Period in Patients with Familial Mediterranean Fever' [2] with interest.

The patients included in our study were referred to the ophthalmology clinic in the acute attack period of familial Mediterranean fever (FMF) during the military service. All patients had been diagnosed with FMF before joining the army. However, the patients were re-evaluated for the diagnosis of FMF based on the Tel Hashomer criteria. The Tel Hashomer criteria were found to have sensitivity and specificity ratios of $>95$ and $>97 \%$, respectively [3]. Some of the patients in our study had data about MEFV gene mutations. That is why we did not perform any correlation between choroidal thickness and genetic data. The genetics of FMF is very complex. To date, $218 \mathrm{MEFV}$ mutations have been defined for the phe- notypic variance seen in FMF [4]. In addition, genetic testing has a $70-80 \%$ positive predictive value, and for this reason the diagnosis of FMF is still made by clinical findings.

The authors reported that they found significantly lower choroidal thickness in the chronic phase of FMF patients. This is plausible, because repeated attacks of inflammation in the choroid may cause fibrosis in the chronic phase and this may cause a decrease in the choroidal thickness. However, this assumption should be verified by longitudinal studies in FMF patients. Apart from our study [2], there is only one study in the literature that investigated the choroidal thickness changes in the acute stage. The authors found an insignificant difference in the retinal and choroidal thickness of children with FMF in the attack-free period [5]. This is also plausible, because one may suggest that the de- crease in the choroidal thickness in the chronic period may only be caused by repeated attacks. Choroidal thickness changes in FMF patients and control subjects should be monitored in a longitudinal study in order to clarify this assumption.

Reported effects of colchicine on the eye are limited in the literature. Intravitreal injection of colchicine has been demonstrated to cause damage to the retinal pigment epithelium and retinal ganglion cells in animal studies [6]. Colchicine-treated eyes showed increased axial elongation and expansion of the vitreous chamber. These effects of colchicine may contribute to thinner choroids in the chronic stage. In our study, most of the patients were not on a regular colchicine treatment. For this reason, we could not evaluate the effect of colchicine on the choroidal thickness.

\section{References}

Kosker M, Bicer T, Celikay O, Gurdal C: Choroidal changes in patients with familial Mediterranean fever. Ophthalmologica 2016, DOI: $10.1159 / 000444061$.

-2 Gundogan FC, Akay F, Uzun S, Ozge G, Toyran S, Genc H: Choroidal thickness changes in the acute attack period in patients with familial Mediterranean fever. Ophthalmologica 2015, DOI: $10.1159 / 000442216$.

3 Livneh A, Langevitz P, Zemer D, Zaks N, Kees $S$, Lidar T, et al: Criteria for the diagnosis of familial Mediterranean fever. Arthritis Rheum 1997;40:1879-1885.

4 Milhavet F, Cuisset L, Hoffman HM, Slim R, El-Shanti H, Aksentijevich I, et al: The infevers autoinflammatory mutation online registry: update with new genes and functions. Hum Mutat 2008;29:803-808.
Erdurmus M, Bekdas M, Demircioglu F, Soydan A, Goksugur SB, Kismet E: Retinal and choroidal thickness in children with familial Mediterranean fever. Ocul Immunol Inflamm 2014;22:444-448.

6 Fortune B, Wang L, Cull G, Cioffi GA: Intravitreal colchicine causes decreased RNFL birefringence without altering RNFL thickness. Invest Ophthalmol Vis Sci 2008;49:255-261.

\section{KARGER}

E-Mail karger@karger.com

www.karger.com/oph (c) 2016 S. Karger AG, Base

0030-3755/16/2353-0185\$39.50/0
Fatih C. Gundogan, MD

Department of Ophthalmology, Gulhane Military Medical Academy Göz Hst AD

TR-06200 Ankara (Turkey)

E-Mail fgundogan@yahoo.com 